\title{
Evaluation of Software Tell Me More for Teaching English : Technology Acceptance Model Approach
}

Septika Ariyanti ${ }^{1}$, Defy Gustianing ${ }^{2}$ and M. Fatkhu Arifin ${ }^{3}$

Aisyah University of Pringsewu, ${ }^{1,2}$; Tidar University of Magelang

septikaariyanti@aisyahuniversity.ac.id ${ }^{1}$;defygustianing@aisyahuniversity.ac.id ${ }^{2}$;

mf_arifin@untidar.ac.id ${ }^{3}$

\begin{abstract}
Knowing the students' technology acceptance about the use of learning media is important because it can measure how far the media's utilisation is.The research purpose is to recognize the significant influence between the variable of Technology Acceptance Model, such as perceived usefulness, perceived ease of use, attitude towards use and behaviour intention in accepting software Tell Me More for teaching English. The participants of this research consisted of 51 students of English Education Study Program from Universitas Muhammadiyah Metro. Questionnaire was used to find out the students' acceptance towards the use of software Tell Me More. Regression analysis is applied to analyze the data. Based on the data analysis through the questionnaire, it is revealed that there was significant influence between the variable of technology acceptance model towards the students' acceptance of Tell Me More software.
\end{abstract}

\begin{abstract}
Abstrak
Mengetahui penerimaan teknologi pada siswa terhadap penggunaan media pembelajaran merupakan suatu yang penting karena dapat mengukur sejauh mana pemanfaatan media tersebut. Tujuan dari penelitian ini adalah untuk mengetahui pengaruh yang signifikan dari variabel - variabel dalam model penerimaan teknologi, yaitu persepsi kegunaan, persepsi kemudahan penggunaan, sikap terhadap penggunaan dan maksud perilaku dalam pengggunaan software Tell Me More untuk pengajaran bahasa Inggris. Partisipan pada penelitian ini adalah siswa program studi Pendidikan Bahasa Inggris Universitas Muhammadiyah Metro sebanyak 51 siswa. Kuesioner digunakan untuk mengetahui penerimaan siswa terhadap penggunaan software Tell Me More. Analisis regresi diterapkan untuk menganalisis data. Berdasarkan analisis data melalui angket diketahui bahwa terdapat pengaruh yang signifikan antara variabel model penerimaan teknologi terhadap penerimaan siswa terhadap software Tell Me More.
\end{abstract}

\section{KEYWORDS}

Technology Acceptance Model, Tell Me More, Teaching English

\section{KATA KUNCI}

Model penerimaan teknologi, Tell Me More, Pengajaran Bahasa Inggris 
Septika Ariyanti ${ }^{1}$, Defy Gustianing ${ }^{2}$ and M. Fatkhu Arifin ${ }^{3}$

J-SHMIC : Journal of English for Academic

Vol 8, No 2, August 2021

\section{INTRODUCTION}

In the process of English language teaching, whether teachers and lecturers try to engage the students to follow and understand the material effectively. One of the ways to achieve the learning objective is by using the media. Now, the availability of learning media are very much beginning from the conventional to sophisticated media. Besides, the existence of technology can create the more appropriate media such as the utilization of computer or laptop in the learning activities.

In the application, the utilization of computer can be more interesting if it is combined with the software, because if the computer was not supported by the good software it will be useless. Now, the technology has provide numerous software that can be used in teaching English. One of the software applications is "Tell Me More Performance". Tell Me More is the worldwide pioneer in dialect learning computer program with more than 9 million fulfilled clients worldwide. Around 25 years, Tell Me More has been an imaginative force within the field of dialect learning. The computer program is the foremost progressed dialect preparing program accessible. Its progressed discourse acknowledgment innovation permits learners to lock in in real-life exchanges and discussions. The program centers on creating the particular aptitudes required to succeed in a dialect, counting: lexicon and linguistic use, tuning in comprehension, verbal expression, composed expression, and social understanding. Tell Me More has been being an inventive drive within the field of dialect learning. More than 10.000 academic institutions have embraced Tell Me More for their language learning needs. Tell Me More have focused on either user's perception ease of use, usefullness, satisfaction, and problem encountered. Besides, Gyamfi, Sukseemuang and Kaewkong (2019) revealed that Tell Me more users' fulfillment did not as it were uncover a high satisfcation with aspects that move forward their scholarly aptitudes (listening, reading and vocabulary) but also the capacity to utilize Tell Me More for self-study, important substance, and its language learning potential.

In this case, one of the colleges which use the Tell Me More in teaching English is Universitas Muhammadiyah Metro. All of the students, especially in English Major, the students must follow interactive learning in the language laboratory for three years. It was happen because to be a great candidate of English teacher it is needed to have qualified skill whether in receptive on productive skill. Therefore, all of the students of English major must follow that activity without exception. The interactive learning is not the compulsory courses, but the students must join it as a additional courses. During following the interactive learning, the students will be provided the software Tell Me More. They did some practices based on their level.

Although the software can help the student in learning English, in the practice, there are some limitations in the use of Tell Me More. It is proven by the preliminary survey to the user of the software, namely the students of Universitas Muhammadiyah Metro. Firstly, some of the students said that they faced difficulties when the software did not respond to what they were saying. Second, when the level was increased, it will be difficult if there was no guidance from the laboratory assistance or the lecturer. Third, they found that their account was lost, whereas they had the satisfying achievement. So, it was not conviniene for them because they had to create a new account. 
The use of Tell Me More Performance at Universitas Muhammadiyah Metro can be seen as one of the way to apply technology in teaching English. Although the software has been used for a long time, it is needed to do an evaluation in order to know how far the software itself can be useful for the students. In this research will be conducted the evaluation towards Tell Me More Performance software. The process of software evaluation will be done by use Technology Acceptance Model (TAM) approach. According to AlAdwan et.al (2013), the Technology Acceptance Model was utilized as the conceptual inquire about e-learning appropriation system. The research too serves an marker of students' acknowledgment of e-learning as well as distinguishing the basic variables that would contribute to its effective utilize.

\section{Technology Acceptance Model}

Technology Acceptance Model basically conducted in investigating the issues in affecting users' acceptance of modern technology system. Priyanka and Kumar (2013) revealed that the Technology Acceptance Model is an extension of Ajzen and Fishbein's Theory of Reasoned Action (TRA). The hypothesis of Technology Acceptance Model was started in 1986 by Fred Davis, and after that it has gone through a few approval and adjustment. Bertrand and Bouchard (2008) explained that the theory aims to reflect the determined factors in technology acceptance, the user attitude towards the technology system and also to show a simple theoretical explanatory model. In conclusion, Technology Acceptance Model (TAM) can be a built model for analyzing and understanding a few components which impact the acknowledgment of the utilize of computer innovation. The objective of TAM is to clarify and anticipate the user's acknowledgment of the data framework.

\section{Perceived Usefulness}

Davis, Bagozzi, and Warshaw (1989) expressed perceived usefulness to consumers' recognitions with respect to the result of the involvement. Concurring to Philips in Bugembe (2010), Usefulness can be characterized as the imminent adopter's subjective likelihood that executing the unused innovation from outside sources will be advantageous to individual or the utilizing the innovation would move forward the way a client might total a given errand.

\section{Perceived Ease of Use}

Davis (1989) expressed that Perceived Ease of Use (PEOU) may be suggested as the degree to which an person, he accepts that employing a specific framework would be free from physical and mental exertion. Venkatesh (2000) detailed perceived ease of use depicts the individual's recognition of how simple the advancement is to memorize and to utilize. Given that a few division of a user's add up to work substance is given to physically utilizing the framework, in case the client gets to be more beneficial in that field of his or her work by means of more noteworthy ease of use, at that point he or she ought to ended up more profitable in general. It implies that the clients features a recognition of how valuable the innovation is in performing their work errands. This incorporates diminishing the time for doing the work, more effectiveness, and precision

\section{Attitude Towards Use}

Davis (1989) revealed that the attitude towards use as the degree how the individuals assess and relate the target framework with their work. The yield of the assessment handle takes the shape of acknowledgment or dismissal towards a innovation. In TAM, attitude towards use is called as an evaluative impact of positive or negative sentiments of people in 
Septika Ariyanti ${ }^{1}$, Defy Gustianing ${ }^{2}$ and M. Fatkhu Arifin ${ }^{3}$

J-SHMIC : Journal of English for Academic

Vol 8, No 2, August 2021

doing a specific behavior. The act of utilizing technology from somebody can be anticipated from the state of mind of his consideration toward certain advances, such as having the inspiration to influence other individuals in arrange to utilize the technology.

\section{Behavioural Intention}

Crescenzi in Irfani (2005) reveals that behavioral intention can be defined as a strong effort from the individual to try or plan to use some particular technology product. The act of using technology from someone can be predicted from the attitude of his attention toward certain technologies, such as having the motivation to persuade other people in order to use technology.

\section{METHOD}

This research applied the quantitative methodology. It means that the data collected and analyzed statistically based on students' score from each Technology Acceptance Model (TAM) variable. The samples of this study were the the students of the third and the fifth semester of English Education Study Program in Universitas Muhammadiyah Metro, which comprises around 51 students. In collecting the information, the questionnaire was applied. Before spreading the questionnaire, the research instrument was conducted the test of reliability and validity. The questionnaire is utilized for measuring the the influence perceived usefulness, perceived ease of use, attitude toward use, and behavioral intention in accepting software Tell Me More. After the information from questionnaire collected, it was analyzed by applying simple linier regression.

\section{FINDING AND DISCUSSION}

a. The Influence perceived usefulness to attitude toward use in accepting software Tell Me More

Table 1. The linier regression result of perceived usefulness to attitude toward use

Model Summary

\begin{tabular}{|l|l|r|r|r|}
\hline Model & R & R Square & $\begin{array}{c}\text { Adjusted R } \\
\text { Square }\end{array}$ & $\begin{array}{c}\text { Std. Error of } \\
\text { the Estimate }\end{array}$ \\
\hline 1 &, $735^{\mathrm{a}}$ &, 540 &, 531 & 7,911 \\
\hline
\end{tabular}

a. Predictors: (Constant), ATU

Coefficients $^{\mathrm{a}}$

\begin{tabular}{|c|c|c|c|c|c|c|}
\hline \multirow{2}{*}{\multicolumn{2}{|c|}{ Model }} & \multicolumn{2}{|c|}{ Unstandardized Coefficients } & \multirow{2}{*}{$\begin{array}{c}\begin{array}{c}\text { Standardized } \\
\text { Coefficients }\end{array} \\
\text { Beta } \\
\end{array}$} & \multirow[b]{2}{*}{$t$} & \multirow[b]{2}{*}{ Sig. } \\
\hline & & $\mathrm{B}$ & Std. Error & & & \\
\hline \multirow[t]{2}{*}{1} & (Constant) & 18,330 & 7,169 & & 2,557 &, 014 \\
\hline & ATU &, 719 &, 095 &, 735 & 7,589 &, 000 \\
\hline
\end{tabular}

a. Dependent Variable: PU

The table over appeared the R-value that demonstrates the relationship between perceived usefulness and attitude towards use with the score of 0,735 . It shows a positive correlation. 
While the R square explains the influence of perceived usefulness to attitude toward use. From the table, it can be known that the $\mathrm{R}$ square value is 0,540 , it implies that the influence perceived usefulness to attitude towards use is $54 \%$ and other variables out of the research influence the rest. Besides, the table also revealed that the P-Value was 0,000 , it means that $\mathrm{P}$ value $<0,05$ and there is any influence. The finding of this research was in line with Yunus, Hasim, Embi and Lubis (2010: 687) who confirmed that the result showed that almost the students agree that Tell Me More software support the students to improve their language ability and around 98,9\% agree that the program is really useful in language learning especially in English. This was likely since the learning was more towards the student-centered. This is also supported by Carmen (2003: 13) who said that with the assistance of ICT (information communication and technology) in the learning process can promote the students to expand their learning competencies and also can improve their communication. Also, the software also provides many activities which give feedback to the student, in order to the student can evaluate their competencies. Furthermore, Li (2012: 187) studied around 160 students attitudes and practices amid independent online learning uncovered the students' positive attitude towards Computer Assisted Language Learning. The participants revealed the adequacy of CALL on their English language capacity. They advanced detailed that the persitent utilize of CALL programs would assist them to illuminate the issues such as ineffective learning technique and retricted vocabulary and listening ability.

\section{b. The influence perceived ease of use to attitude towards use in accepting software Tell Me More}

Table 2. The linier regression result of perceived ease of use to attitude toward use

Model Summary

\begin{tabular}{|l|r|r|r|r|}
\hline Model & $\mathrm{R}$ & R Square & $\begin{array}{c}\text { Adjusted R } \\
\text { Square }\end{array}$ & $\begin{array}{c}\text { Std. Error of } \\
\text { the Estimate }\end{array}$ \\
\hline 1 &, $744^{\text {a }}$ &, 554 &, 545 & 9,926 \\
\hline
\end{tabular}

a. Predictors: (Constant), ATU

Coefficients $^{\mathrm{a}}$

\begin{tabular}{|c|c|c|c|c|c|c|}
\hline \multirow{2}{*}{\multicolumn{2}{|c|}{ Model }} & \multicolumn{2}{|c|}{ Unstandardized Coefficients } & \multirow{2}{*}{$\begin{array}{c}\begin{array}{c}\text { Standardized } \\
\text { Coefficients }\end{array} \\
\text { Beta }\end{array}$} & \multirow[b]{2}{*}{$\mathrm{I}$} & \multirow[b]{2}{*}{ Sig. } \\
\hline & & $B$ & Std. Error & & & \\
\hline \multirow[t]{2}{*}{1} & (Constant) & 6,806 & 8,994 & & ,757 & 453 \\
\hline & ATU &, 926 & 119 & ,744 & 7,796 &, 000 \\
\hline
\end{tabular}

a. Dependent Variable: PEOU

The table above showed the value of $\mathrm{R}$ that indicates the relationship between perceived ease of use and attitude towards use, and with the score 0,744. It revelaed a positive correlation. While the $\mathrm{R}$ square explains the influence perceived ease of use to attitude toward use. The table implied that the $\mathrm{R}$ square value is 0,554 , it means that the influence perceived ease of use to attitude toward use is $55,4 \%$ and other variables out of the research influence the rest. Besides, the table also explained that the P- value was 0,000, it means that $\mathrm{P}$-value $<0,05$ and there is any influence. 
This finding is line with the study of Shroff, Deneen, and $\mathrm{Ng}$ (2011: 609) which is the result of the research implied that perceived ease of use illustrated a influence on attitude toward use (path=0,30). Then, Davis (1989: 319) who states that perceived ease of use had an impact on attitude towards use. An clarification might be that when students seen the e-portfolio system as one that is simple to use and free of mental exertion, they may have a favorable attitude towards the usefulness of the framework. Moreover, Yunus, Hasim, Embi and Lubis (2010: 687) said that the findings show that the large part of students concurred that Tell Me More software is simple to utilize, likely since the students found the language used in the software was obvious and simple to get in. Lastly, Ishak and Shafinah (2006: 80) reveal that student would feel more pleasant and open to acknowledge any error through the full learning actvity, as the learning process is between the students themselves and the computer. Therefore, it makes a non-threatening surrounding where the students lower affective filter and ideally more learning takes put.

\section{c. The influence perceived of usefulness to behavioral intention in accepting software Tell Me More}

Table 3. The linier regression result of perceived of usefulness to behavioral intention

Model Summary

\begin{tabular}{|l|c|r|r|r|}
\hline Model & $\mathrm{R}$ & R Square & $\begin{array}{c}\text { Adjusted R } \\
\text { Square }\end{array}$ & $\begin{array}{c}\text { Std. Error of } \\
\text { the Estimate }\end{array}$ \\
\hline 1 &, $688^{\mathrm{a}}$ &, 474 &, 463 & 8,466 \\
\hline
\end{tabular}

a. Predictors: (Constant), BI

Coefficients $^{\mathrm{a}}$

\begin{tabular}{|c|c|c|c|c|c|c|}
\hline \multirow{2}{*}{\multicolumn{2}{|c|}{ Model }} & \multicolumn{2}{|c|}{ Unstandardized Coefficients } & \multirow{2}{*}{$\begin{array}{c}\begin{array}{c}\text { Standardized } \\
\text { Coefficients }\end{array} \\
\text { Beta }\end{array}$} & \multirow[b]{2}{*}{$t$} & \multirow[b]{2}{*}{ Sig. } \\
\hline & & $\mathrm{B}$ & Std. Error & & & \\
\hline & (Constant) & 33,951 & 5,864 & & 5,790 &, 000 \\
\hline & $\mathrm{BI}$ &, 539 &, 081 &, 688 & 6,639 &, 000 \\
\hline
\end{tabular}

a. Dependent Variable: PU

The table above showed the value of $\mathrm{R}$ that indicates the relationship between perceived usefulness and behavioral intention, with the score of 0,688. It shows a positive correlation. While the R square explains the influence perceived of usefulness to behavioral intention. The table showed that the R square value is 0,474 , it means that the influence perceived ease of use to attitude toward use is $47,4 \%$ and other variables out of the research influence the rest. Besides, the table also revealed that the $\mathrm{P}$-value was 0,000 , it means that $\mathrm{P}$-value $<0,05$ and there is any influence.

This finding was in line with Tanduklangi (2017: 75), who affirms that there's a positive and affect of value on the usefulness of purposeful in utilizing e-Learning. This finding infers that the students accept e-Learning as being advantageous, which can assist influence the purposeful of embracing e-Learning. At that point, Zanzani and Ramazani (2012: 291) demonstrated that perceived of usefulness implied a positive impact on the acknowledgment of 
innovation from the perspective of understudies and instructors of English Language. In addition, agreeing to Chapelle as cited in Yunus (2010: 690), the positive affect was characterized as the positive impacts of the CALL movement on those who took part in it. Almost all of the understudies (97.6\%) detailed that they just like the exercises within the software and they would like to spend more time utilizing the application. Here, the students did not only learn the modern words and see the associated pictures on the site but moreover need to tune in to the right articulation of the words. This kind of exercises advances dynamic learning in this way pulled in students' interest.

\section{d. The influence of students' attitude to behavioral intention in accepting software Tell Me More}

Table 4. The linier regression result of students' attitude to behavioral intention

Model Summary

\begin{tabular}{|l|r|r|r|r|}
\hline Model & $\mathrm{R}$ & R Square & $\begin{array}{c}\text { Adjusted R } \\
\text { Square }\end{array}$ & $\begin{array}{c}\text { Std. Error of } \\
\text { the Estimate }\end{array}$ \\
\hline 1 &, $862^{\text {a }}$ &, 742 &, 737 & 6,060 \\
\hline
\end{tabular}

a. Predictors: (Constant), $\mathrm{BI}$

\begin{tabular}{|c|c|c|c|c|c|c|}
\hline \multicolumn{7}{|c|}{ Coefficients $^{a}$} \\
\hline \multirow{2}{*}{\multicolumn{2}{|c|}{ Model }} & \multicolumn{2}{|c|}{ Unstandardized Coefficients } & \multirow{2}{*}{$\begin{array}{c}\text { Standardized } \\
\text { Coefficients }\end{array}$} & \multirow[b]{2}{*}{$t$} & \multirow[b]{2}{*}{ Sig. } \\
\hline & & $\mathrm{B}$ & Std. Error & & & \\
\hline \multirow[t]{2}{*}{1} & (Constant) & 25,971 & 4,197 & & 6,187 &, 000 \\
\hline & $\mathrm{Bl}$ & ,691 &, 058 & ,862 & 11,880 &, 000 \\
\hline
\end{tabular}

a. Dependent Variable: ATU

The table above showed the value of $\mathrm{R}$ that indicates the correlation between attitude toward use and behavioral intention, and the score is 0,862 . It shows a positive correlation. While the $\mathrm{R}$ square explains the influence attitude toward use to behavioral intention. The table showed that that the $\mathrm{R}$ square value is 0,742 , it means that the influence attitude toward use to behavioral intention is $74,2 \%$ and other variables out of the research influence the rest. Besides, the table also revealed that the P-value was 0,000 , it implied that $\mathrm{P}$-value $<0,05$ and there is any influence.

This finding is supported by Sabti and Chaichan (2014: 6) reveals the learners reaction was for the most part being positive toward the utilization of computer and the web in learning English. The learners communicated that technology-based classrooms moved forward their learning activity. The roundly mean score of the attitude toward computer technologies were 3,3667 for male companions and 3,6056 for female companions out of 5. This likely demonstrated that participants had indicated a high level of recognition of noteworthiness of employing computer technologies in the learning English Activity. 
Septika Ariyanti ${ }^{1}$, Defy Gustianing ${ }^{2}$ and M. Fatkhu Arifin ${ }^{3}$

J-SHMIC : Journal of English for Academic

Vol 8, No 2, August 2021

e. The influence perceived ease of use to perceived usefulness in accepting software Tell Me More

Coefficients $^{\mathrm{a}}$

\begin{tabular}{|c|c|c|c|c|c|c|}
\hline \multirow{2}{*}{\multicolumn{2}{|c|}{ Model }} & \multicolumn{2}{|c|}{ Unstandardized Coefficients } & \multirow{2}{*}{$\begin{array}{c}\begin{array}{c}\text { Standardized } \\
\text { Coefficients }\end{array} \\
\text { Beta } \\
\end{array}$} & \multirow[b]{2}{*}{$t$} & \multirow[b]{2}{*}{ Sig. } \\
\hline & & $\mathrm{B}$ & Std. Error & & & \\
\hline \multirow[t]{2}{*}{1} & (Constant) & 23,187 & 10,848 & & 2,137 & ,038 \\
\hline & PU &, 734 & 149 &, 576 & 4,937 &, 000 \\
\hline
\end{tabular}

a. Dependent Variable: PEOU

Table 5. The linier regression result of perceived ease of use to perceived usefulness

The table showed that the R-value that implied the relationship between perceived ease of use and perceived of usefulness, and the score is 0,576 . It shows a positive correlation. While the $\mathrm{R}$ square explains the influence perceived ease of use to perceived usefulness. The table also revealed that the $\mathrm{R}$ square values is 0,332 , it signified that the influence perceived of usefulness to perceived ease of use is $33,2 \%$ and the rest is influenced by others variable out of the research. Besides, the table also revealed that the P-value was 0,000 , it means that Pvalues $<0,05$ and there is any influence.

\section{CONCLUSION}

This research is focus on recognize the influence between the variable of Technology Acceptance Model. In summary, the result of linear regression analyses confirmed the five hypotheses. Attitude Toward Use had the highest influence to Behavioural Intention, taken after by the positive influence of perceived ease of use in using software Tell Me More. Besides, perceived usefulness had positive influence to attitude toward use and also perceived usefulness had positive influence to behavioural intention. Finally, perceived ease of use had the lowest influence to perceived usefulness. In this case, the influence of perceived ease of use has a low effect on perceived usefulness. It has proven although most students revealed that the use of software Tell Me More still finding some difficulties, such as the software did not work for a moment, the word pronunciation was not clear enough, the student still get some advantages from software Tell Me More such as improving their vocabulary, sharping their listening and training their speaking.

To sum up, the findings of this research were relevant to the theories and previous study related to the technology acceptance model. Concurring to the elaboration above, it can be deduced that the participants can accept the utilization of technology from software Tell Me More in the process of learning English. Regarding research result, it is important for giving some suggestions in order to make a better quality of English language teaching. Firstly, the teachers or lectures is expected can give some motivation to the students related the use of software Tell Me More which can help the students to improve their English ability. Secondly, by knowing the result of this research hopefully, the students can accept the 
Septika Ariyanti ${ }^{1}$, Defy Gustianing ${ }^{2}$ and M. Fatkhu Arifin ${ }^{3}$

J-SHMIC : Journal of English for Academic

Vol 8, No 2, August 2021

software Tell Me More in a good way and use it in the process of learning process continuously. Thirdly, it is suggested to other researchers to conduct similar research related to the Technology Acceptance Model toward some language learning software.

\section{ACKNOWLEDGEMENTS}

We would to express our gratitude to Yasmika Baihaqi as a Head Language Institute of Universitas Muhammadiyah Metro who allowed us to conduct the research and also to all students which participate in this research.

\section{REFERENCES}

Al-Adwan, Amer., Al-Adwan, Ahmad., and Smedley Jo. (2013). Exploring Students Acceptance of E-Learning Using Technology Acceptance Model in Jordanian University. International Journal of Education and Development Using Information and Communication Technology (IJEDICT). Vol 13, 4- 18

Bugembe, Juliet. 2010. Perceived Usefulness, Perceived Ease of Use, Attitude and Actual Usage of a New Financial Management System: A Case Study of Uganda National Examination Abroad. Uganda: Makarere University Business School

Bertrand, Manon and Bouchard, Stephane. 2008. Applying The Technology Acceptance to VR With People Who Are Favorable to Its Use. Journal of Cyber Therapy and Rehabilitation. Vol. 1. Issue 2

Carmen et al. (2003). Use of ICT and Perception of E-Learning Among University Students: A Differential Perspective According to Gender and Degree Year Grop. Interactive Educational Multimedia. No. 7

Creszenci,A. 2005. User Acceptance of Electronic Meeting Technology in The Semiconductor Research Corporation. Chapel Hill: North Carolina University

Davis, F.D. 1989. Perceived Usefulness, Peceived Ease of Use and User Acceptance of Information Technology. MIS Quarterly. 13

Davis, F.D., Bagozzi, R.P and Warshaw, P.R. (1989). User Acceptance of Computer Technology: A Comparison of Two Theoretical Models. Management Science. $35(8)$

Ishak,WI and Shafinah,M.S. 2006. Utilizing ESL Websites as Learning Tool to Learn English. Online Teaching and Learning in ELT. Penang: Penerbit USM

Gyamfi, George.,Sukseemuang, Panida and Kaewkong, Pittayatorn. (2019). Self-Study with the Educational Technology Tell Me More: What EFL Learners do. Open Praxis. Vol 11. Issie 1

Priyanka, S dan Kumar, A. (2013). Understanding The Evolution of Technology Acceptance Model. International Journal of Advance Research in Computer Science and Management Studies. 1(6)

Sabti, Ahmed Abdulateef., and Chaichan, Rasha Sami. 2014. Saudi High School Students' Attitudes and Barriers Toward The Use of Computer Technologies In Learning English. Springer Plus. 3:460

Shroff, Ronnie H., Deneen, Christoper C., and Ng Eugenia M.W. (2011). Analysis of The Technology Acceptance Model in Examining Students' Behavioural Intention to Use an E-Portofolio System. Australian Journl of Educational Technology. 27(4) 
Septika Ariyanti ${ }^{1}$, Defy Gustianing ${ }^{2}$ and M. Fatkhu Arifin ${ }^{3}$

J-SHMIC : Journal of English for Academic

Vol 8, No 2, August 2021

Tanduklangi, Amri. (2017). Determinants of User Intention in Using E-Learning Technology in Indonesian Context: An Empirical Study. Mediterranean Journal of Social Sciences. 8(3).

Venkatesh, Viswanath. (2000). Determinants of Perceived Ease of Use: Integrating Control, Motivation, and Emotion into The Technology Acceptance Model. Information System Research.11(4)

Yunus, Melor Md., Hashim, Arwati, Embi Mohamed A., and Lubis, Maimun A. (2010). The Utilization of ICT in The Teaching and Learning of English: 'Tell Me More'. Procedia Social and Behavioral Science. 9

Zanzani, Farnaz Vali Moghaddan., and Ramazani Morteza. 2012. Investigation of E-Learning Acceptance in Teaching English Language Based on TAM Model. ARPN Journal of Systems and Software. Vol 2, No. 11 